\title{
Usability of ICT as a Tool for Professional Development of Teachers at Secondary Level
}

\author{
Abdul Khaliq ${ }^{1}$ \\ Prof. Iftikhar Ahmad Baig ${ }^{2}$ \\ Dr. Khuda Bakhsh ${ }^{3}$ \\ Muhammad Shafiq Ahmad ${ }^{4}$
}

\begin{abstract}
The use of information and communication technology (ICT) has been influencing every field of human life including education sector all over the world since its inception. Although Pakistan is a developing country but like other developed countries of the world, its teachers are trying to use ICT in their teaching learning activities to improve their existing knowledge, skills, and other competencies because ICT helps teachers in enhancing their morale, personal and professional development. In this regard, a very few studied have been conducted to explore the usability of ICT as a potential tool for professional development teachers in Pakistan. Therefore, the aim of the present study is to explore the perceptions of research subjects regarding the usability of ICT as a tool for professional development of public sector secondary school teachers of the province Punjab, Pakistan. The sampling population of the present study is comprised of all head teachers, secondary school teachers of public schools, and master trainers of Directorate of Staff Development who are engaged in professional development of secondary school teachers in Faisalabad division. A sample of 296 research subjects (head teachers $n=84$, secondary school teachers $n=175$, and master trainers $n=$ 37) is drawn through proportionate stratified random sampling technique. A cross sectional survey is conducted to explore the perceptions of respondents of the study. A self-developed and structured questionnaire is used as a research instrument on a five point Likert rating scale, and all psychometric properties (e.g., reliability and validity) were ensured in the development of the final version of the research instrument. The Mean and Standard Deviation are used as descriptive statistics, while one-way between groups ANOVA as inferential statistics. It is recommended that Punjab Education Department should conduct effective information and communication technology based trainings, workshops, and refresher courses for the proper usability of ICT at secondary level public sector schools; and for the improvement of information and communication technology based knowledge and skills of secondary school teachers.
\end{abstract}

Keywords: ICT, Usability, secondary school teachers, professional development, public sector.

\section{INTRODUCTION}

Education is one of the key players for the solidarity and sustainable development of a nation; and it plays a fundamental role in cognitive, affective, psychomotor, socioeconomic, and cultural development of citizens of a nation. Education is also an indispensable tool for the Human Resource Development of a nation. No nation can achieve its desired aims without providing quality education to its citizens, and quality education generally depends on the

1 - PhD Scholar, The University of Lahore, Lahore, Email: khaliquol@gmail.com

2 - Head of Department (Education), The University of Lahore, Lahore.

- Assistant Professor, Government College University, Faisalabad.

4 - PhD Scholar, Government College University, Faisalabad.

JISR-MSSE

Volume 1

Number 15

Jan-June 2017 
quality of teachers. Also, the provision of quality education usually depends on the professional development of teachers. Professional development refers to such programs, practices, and activities that enhance an individual's knowledge, skills, and other attributes as being a teacher, so, that he/she can perform his/her task effectively. Professional development is not a single teacher activity; it is a collaborative and ongoing process that takes place among teachers, between teachers and administrators, between teachers and parents, and between teachers and other community members (Grace, 1999).

According to National Education Policy of Pakistan (2009), the performance of our teachers is not satisfactory and our education system has failed in achieving its prescribed educational goals. The poor quality of teachers in the education system in a huge quantity is a matter of concern for all stakeholders. In this education policy, it was greatly emphasized that all teachers shall have opportunities for their professional development through a program conducted on the basis of a three-year cycle. Their promotion in career shall be associated with such professional development programs. In-service teacher training programs will be based on real life situations and accordingly the needs of the students and present education scenario. In-service training shall cover various aspects such as pedagogy and pedagogical content knowledge; assessment and evaluation; multi-grade teaching, monitoring and evaluation; and programs for fulfilling the emerging needs like trainings in information and communication technology. The modern technologies such as ICT will be used for professional development of in-service teachers. For better utilization of ICT for professional development, the proper training will be given according to the needs of the teachers (NEP, 2009).

In the present scenario, it needs to adopt and integrate ICT for the professional development of teachers in education system of Pakistan, where teachers' self-efficacy, efficiency and effectiveness is very low, which is an alarming situation for concerned authorities, stakeholders and policy makers because without the adoption and integration of ICT in education system, teacher cannot cope with the modern challenges in the every sphere of human life. In this regard, Directorate of Staff Development has launched a program for the provision of ICT based knowledge and skills for teachers and school managers. Furthermore, Directorate of Staff Development has also planned to employ only those potential personnel having a sufficient and effective knowledge and skills of ICT tools in Directorate of Staff Development. According to Directorate of Staff Development and UNESCO (2010) ICT will be made mandatory for teacher education in the coming years. So, Directorate of Staff Development is trying to prepare such potential personnel in education system that can enhance quality of education and produce quality products in their institutions which can compete with modern challenges in every sphere of life.

Now-a-days great stress has been given to the teachers' training particularly at the secondary level to improve secondary school teacher pedagogical competencies in Pakistan. In-service training is being provided on the assumption that teachers are not innate teachers, there is always need to train them according to new emerging trends, paradigms and innovations in the education sector. In the modern world where new inventions and innovations are transforming the ways of life and the content matter of every subject is expanding at a very tremendous rate. Consequently, it is impossible for a teacher to study new areas with his/her own efforts and resources. The teaching methods and techniques are continuously transforming, and new paradigms, models, and theories are emerging in education system. There is always need to 
acquire training of new teaching methods and techniques so that teachers can efficiently cope with the challenges which are mitigating their efficiency and effectiveness in classroom setting.

Teachers can play a key role in the prosperity and sustainable progress of a nation; and they are considered as a backbone of the education system throughout the world. Every nation has its specific objectives and aims; and these could not achieve without the provision of quality education to its students. With the advancement in society, it is necessary for teachers to enhance their knowledge and skills; so, they can run with the pace of time (Razzak, 2013).

The professional development of teachers is very important for the improvement of their personal development, classroom practices, and students' achievement (Carlson \& Gaido, 2002). There is a burning need in schools to use information and communication technology, so that teachers could attain more and more information and communication technology based knowledge, skills, and other competencies, which should be meaningful and beneficial for teachers, to teach their lessons sufficiently, and consequently, they could deliver quality education to their students.

The rapid growth and development in information and communication technology has brought significant changes, interventions, and innovations in the twenty-first century. As well as, information and communication technology holds a key status as an indispensable tool in the present day education system throughout the world. information and communication technology covers all forms of computer and communications' equipment and software used to create, design, store, transmit, interpret, and manipulate information in various formats. Personal computers, Internet, laptops, palmtop, tablets, mobile phones, transport systems, televisions, and network technologies are just some examples of information and communication technology (Clausen, 2007).

According to Davis (2000), information and communication technology provides teachers with a broad range of new tools, techniques, and strategies for the improvement of traditional pedagogies and classroom practices; it also assists teachers with the potential to build up new teaching methods, techniques, and strategies (Abuhmaid, 2011; Carlson \& Gaido, 2002). To bring improvement in the education sector, information and communication technology provides new, and more exciting and relevant learning modes and opportunities both for the teachers and students (Neyland, 2011).

In order to integrate and use information and communication technology in the education system, teachers need to adapt and improve their existing teaching and learning practices, according to the newest trends in the education system, from a conventional style and teacher dominated way of teaching, to a more interactive method and learner-centered with the help of information and communication technology (Andoh, 2013).

Consequently, the presented study is conducted to explore the perceptions of public secondary school head teachers, secondary school teachers, and master trainers regarding the use of information and communication technology for professional development of the secondary school teachers in the province Punjab, Pakistan. 


\section{Statement of the Problem}

The teachers' professional development is very important, and it plays a significant role in the enrichment of teachers' current knowledge and skills. In this age of globalization, different tools and techniques are being used for the improvement of professional development of teachers. Information and communication technology is one of them, by which teachers' knowledge and skills can be enhanced, upgrade, and update because information and communication technology and professional development are complementary to each other. Information and communication technology provides opportunities and access to teachers to increase their knowledge and skills; and improve their pedagogy and classroom practices. Therefore, the aim of conducting this study is to explore the effect of usability of information and communication technology on professional development of secondary school teachers.

\section{Resource Based View in Higher Education}

The following objectives guided the present study:

- To explore the secondary school teachers' attitudes towards the use of ICT for their professional development,

- To suggest recommendations for the proper usability of ICT in pedagogical activities of secondary school teachers.

\section{Research Question}

Consistent with the objectives, the study was driven by following research question:

- What attitudes do the secondary school teachers have towards the use of information and communication technology for their professional development?

\section{Significance of the Study}

The present study may be significant in educational context of Pakistan, because it would provide knowledge and skills towards the use of ICT as a pedagogical tool concerned to secondary school teachers in public sector school in Pakistan. The notion of using information and communication technology as a pedagogical tool and/or technique is really innovative for a majority of teachers at secondary level. The use of information and communication technology in teaching may definitely modify the quality of teaching-learning process. This empirical study may play a significant role for secondary school teachers in Pakistan, who want to learn and attain more knowledge and skills about the usability of information and communication technologies. The findings of the study may create awareness among public school teachers about the significance of information and communication technology as an instructional tool and may transform their perceptions and teaching practices. Also, the findings of this study may also serve a reference point for educational stakeholders for future planning regarding professional development of secondary school teachers, and for the fulfillment of their professional needs.

\section{Justification of the Study}

The rationale of the selecting this particular area of study is to explore the perceptions of the respondents regarding the use of information and communication technology (ICT) as a potential tool for professional development of secondary school teachers of public sector. And to

120 Jan-June $2017 \quad$ Volume $1 \quad$ Number $15 \quad$ JISR-MSSE


integrate information and communication technology in teaching practices of secondary school teachers in province Punjab, Pakistan. Information and communication technology based professional development programs can more help teachers to improve and update their current knowledge, skills, and competencies; and also other core areas of their personal and professional development. Because, ICT based professional development programs are very essential to improve educational practices as they allow teachers to gain new information that is essential for creating conducive and healthy classroom environment. In order to use ICT in education system effectively, secondary school teachers must need to adapt and improve their existing teaching and learning practices according to the newest trends in education system, from a conventional style and teacher dominated way of teaching to an interactive and learner-centered methods with the help of ICT.

\section{LITERATURE REVIEW}

The significance of professional development for all tiers of teachers has been greatly stressed in every education policy and plan since the inception of Pakistan. The first Education Conference (EC) was continued from 27-11-1947 to 1-12-1947. It was presided by Mr. Fazal-ur-Rehman, the first Education Minister of the Islamic Republic of Pakistan. In this education conference, it was decided to set up different sub-committees to study and discuss various problems and challenges related to the present education system in Pakistan. The committee about teacher education and professional development reported that an efficient and effective teaching profession is indispensable for the building and sustainable development of this new Islamic state (Govt. of Pakistan, 1947). This committee further proposed that proper teacher training and a suitable salary structure are necessary for the improvement of the education sector in the country.

The Commission on National Education (1959) has also stressed upon the fundamental role of teachers in the education system in these words, "No system of education can go up above the teachers who serve it, and the quality of any education system mostly depends on the quality of its teachers" (Govt. of Pakistan, 1959). This commission further pointed out that teachers should have proper subject's knowledge which they teach; and also acquire potential professional training so that our national educational goals and aims could be achieved. This commission highlighted that proper teachers' training or professional development is essential to understand individual differences, curriculum development, teaching methodology and classroom assessment, particularly at the secondary level. The development and enrichment of any education system basically depends upon the quality of its teachers. Quality education can play its potential role if we conduct quality teacher education programs for professional development of teachers (Govt. of Pakistan, 1965).

The Education Policy 1969-70 recommended that there should be established a separate directorate, working as an autonomous body, and this directorate should be headed by a Director General (DG) for recruitments and teachers' education (Govt. of the Pakistan, 1969). The NEP 1972-80 has also greatly stressed on the teachers' training skills. In this national education policy the significance and need of teachers' education are highlighted in these words, "The facilities for teachers will be enhanced by reorganizing teacher education".

It was recommended in this education policy that an academy, on the pattern of academics existing for finance and civil services should be established for teachers and educational 
planners/administrators (Govt. of Pakistan, 1972-80). The importance of teacher education has also been greatly stressed in National Education Policy 1998-2010. According to this policy the quality of teachers' education is directly associated with quality of teaching in classroom settings. Teachers are regarded as the most fundamental element in the implementation of education reforms at the bedrock level. It is true that teachers' personal experience, qualification and knowledge about subject matter, competence and skills of teaching and the teachers' motivation, dedication and commitment are considered important both for the teachers and learners.

The term information and communication technology has changed its focus gradually with the passage of time and refers to a number of specific facets of usability of technology within the school, education, and the application of technology to assist teaching and learning process across the curriculum (Twining \& Henry, 2014). Modern technologies and the ways of using these technologies are radically transforming school environment across the globe. According to Mwalongo (2011), the successful integration of information and communication technology in teaching-learning activities basically depends on teachers' attitude towards using information and communication technology. Now information and communication technology based tools are bringing dynamic and potential changes and interventions in the education system throughout the world.

Now developing countries are also spending a lot of resources in information and communication technology to solve pedagogical issues and improve classroom practices (Haddad \& Jurich, 2002; Yukselturk \& Bulut, 2009). Pakistan has also participated in this race for becoming a technological sufficient country, and since from the very beginning of the HEC, Information Technology promotion in educational institutions were given high priority, and then, government allocated huge funds for the promotion of Information Technology sector. In this regard, Information Technology Action Plan and Policy (2000) was developed; and Dr. Atta-ur-Rehman, the Federal Minister of Information Technology announced IT policy in the year 2000 (Government of Pakistan,2000).

Teachers can play a vital role in the improvement of learning outcomes. Their beliefs, experiences, aspirations, job satisfaction, knowledge, skills, morale, self-efficacy, and motivation all are important in overall school development. Their perceptions and activities toward improving their instructional activities are affected by what teachers perceive. Consequently, prioritizing teacher professional development and teacher education are significant in ICT integration and improving classroom activities. Moreover, the application of ICT in education system as an instructional medium or technology not only improves teaching-learning but it is also essential in the preparation of the pedagogues to compete the challenges of globalization. Therefore, the usability of information and communication technology not only share knowledge, skills but also improves human capital which sets technological innovations and economic growth (Kisirkoi, 2015).

As far as professional development deals with the improvement of teachers' knowledge and skills, therefore, teachers can update their knowledge and improve skills if they are sincere, committed, and dedicated in their efforts. Teachers are the key knowledge producers and the key development driving force of any nation (Norris, Sullivan, Poirot, \& Soloway, 2003). The teachers' training on the latest knowledge, skills, and competencies for personal and career

122 Jan-June 2017 Volume $1 \quad$ Number $15 \quad$ JISR-MSSE 
development of pedagogues is necessary for attaining sustainable societal and cultural development of a nation (Cope \& Ward, 2002).

According to Al-Madani and Allaafiajiy (2014) for successful ICT use in teaching and learning activities needs to enhance teachers' knowledge, skills, morale, and confidence towards ICT with the provision of ICT software and hardware facilities. Moreover, teachers' professional development assists in updating their current knowledge, skills, and other attributes of the teachers, and makes it possible through which they can share their knowledge and skills with one another.

But Semenov (2005) argues that computers are insufficient to accomplish the profligate promises of technology. Because the successful adoption and integration of information and communication technology in education system depends on the participation of teachers because it is not technology that build up teaching-learning process effective, but also the efforts, methodology, techniques, strategies, and contributions of teachers individually and collaboratively (Passey \& Samways, 1997). Majoka, Fazal, and Khan (2013) also conducted a study in Pakistan and found that teachers have insufficient knowledge and skills toward ICT use in their pedagogical activities.

Teachers' continuous professional development is a key performance indicator for a nation's growth and development. On the other side, the use of computers, Internet, e-mail, and smart phones in the education system has been growing rapidly in the last few decades (Condie \& Livingston, 2007; Cubukcuoglu, 2013). Therefore, several countries of the global village are investing their more and more resources for information and communication technology based technologies in education system to update and upgrade teachers' knowledge, skills, and competencies; and for the improvement of students' achievement and learning outcomes.

Information and communication technology can play significant roles in enhancing PD of teachers throughout the world. According to Brinkerhoff (2006), several studies have reviewed literature on information and communication technology and PD; and explored that information and communication technology has powerful potential to enhance knowledge, skills, efficiency, and effectiveness of teachers in their professional matters and students' achievement. Now, information and communication technology is being considered as an integral part of our life; and information and communication technology is also playing vital roles in education.

In a study, Bonifacio (2014) investigated that the use of ICT can support new instructional approaches and instructional methods such as cooperative learning and simulation, etc. Furthermore, ICT has significant potential to improve teachers' teaching-learning outcomes and effectiveness. ICT also allow teachers to attain adequate subject knowledge, a collection of teaching strategies techniques, and professional development for their lifelong learning. He further elaborated that use of ICT in teaching requires not only the development of knowledge, skills, and competencies but there should be teachers' positive attitudes towards ICT.

According to Twining et al. (2015), generally ICT training for pedagogues is only based on developing their computer literacy, which is a key element for the integration of ICT in pedagogical activities; yet it is remarkable that training should not be only stopped at teachers' 
computer literacy but its focus should be on effective teaching practices. Therefore, teachers training concerned to ICT in education, is also related to existing infrastructure, and all teachers should be trained to use ICT in their classroom activities.

The use of information and communication technology facilitates teachers to save time; and consequently, it enhances educational productivity. At the present time, teachers are using computer and Internet to prepare their work more proficiently (Campbell, 2001). The application of computer, Internet, and multimedia in teaching, enhances teachers' motivation and improve teaching- learning process (Grabe \& Grabe, 2001); also the use of information and communication technology in classroom activities improves teachers' self-efficacy (Chanlin, Hong, Horng, Chang, \& Chu, 2006; Roger, 2003).

ICT provides an easy and swift access to attain information that can easily store and retrieve from the computers on demand. It also saves the users' time. ICT also helps teachers to improve their quality of work. ICT has made it simple for teachers to update and upgrade teaching and learning material on internet (Ali, Haolader, \& Muhammad, 2013). They also suggested that teachers' training in pedagogical issues should be enhanced so that teachers could improve their pedagogical activities.

In a descriptive study, Ndibalema (2014) found that teachers at secondary level in Tanzania have positive attitudes toward the usability of information and communication technology as a teaching tool but they were unable and incompetent to integrate ICT in their teaching learning practices successfully. Moreover, due to lack of proper familiarity with ICT gadgets teachers cannot use as a pedagogical tool in instructional activities.

In a study, Hasibuan (2013) found that ICT based competencies enables to teachers to perform teaching and learning activities effectively. He also reported that ICT based infrastructure and facilities in schools are very significant about the development of teachers' professional competence. In the educational system, information and communication technology has altered the paradigm of to instruct learners in classroom settings. Therefore, ICT not only facilitate teachers in teaching practices, but it also enable to teachers to transform their learning process.

Information and communication technology in education lives a life at the crossroads between evidence-based policy making, learning and the fast changing world of technology. In modern education system, information and communication technology can be seen as, to improve the teaching and learning activities; and permit for various perspectives on different trends pertinent to teachers' professional development (Armstrong, 1999; Wee \& Bakar, 2006). Consequently, information and communication technology not only impacts on teaching-learning activities, but also influences on the modes and opportunities through which teachers teach and learn.

According to Ajzen (1998), now teachers can prepare their lessons with the assistance of information and communication technology for the provision of quality education to the students throughout the world. Therefore, the use of information and communication technology in education system is to allow teachers to enhance their knowledge and skills potentially and actively in various learning environments individually and collaboratively.

124 Jan-June $2017 \quad$ Volume $1 \quad$ Number $15 \quad$ JISR-MSSE 
Information and communication technology based professional development programs for teachers help them to improve knowledge, skills, and competencies; and other core areas of their personality development. ICT based professional development programs are essential to improve educational practices as these allow teachers, to gain new information and skills which are required for creating a classroom's environment conducive and healthy.

\section{RESEARCH DESIGN}

This study is descriptive survey type in nature. The quantitative approach is used to conduct this study. A quantitative approach provides valuable information if the researcher wants to generalized the results of the study to the target population (Creswell, 2005).

The target population or universe of this empirical study was consisted of all Punjab public secondary schools' teachers and head teachers, and master trainers of Directorate of Staff Development in province Punjab. The sampling population is comprised of 1,746 secondary school teachers, 838 head teachers of public secondary school in Faisalabad division, and 122 master trainers of the Directorate of Staff Development who are engage in secondary school teachers' professional development in four districts (e.g., Chiniot, Jhang, Faisalabad, Toba Tek Singh) of the Faisalabad division.

Through proportionate stratified random sampling technique, a sample of 175 secondary school teachers, 84 head teachers, and 37 master trainers is drawn. Because the present research is quantitative by approach, consequently, proportionate stratified random sampling technique was an appropriate sampling technique, when there were different strata and the accessible population was heterogeneous.

Table.1 Number of Respondents selected from each District in Sample

\begin{tabular}{ccccc} 
Sr.\# & Districts & Head Teachers & Secondary School Teachers & Master Trainers \\
\hline $\mathbf{1}$ & Faisalabad & 44 & 103 & 21 \\
$\mathbf{2}$ & Jhang & 15 & 25 & 6 \\
$\mathbf{3}$ & Chiniot & 7 & 13 & 2 \\
$\mathbf{4}$ & Toba Tek Singh & 18 & 34 & 8 \\
\hline Total & $\mathbf{-}$ & $\mathbf{8 4}$ & $\mathbf{1 7 5}$ & $\mathbf{3 7}$
\end{tabular}

A self-developed and structured questionnaire was used as a research instrument, and all psychometric properties (e.g., reliability and validity) were ensured in the development of final version of the research instrument. The perceptions of the respondents were measured on a five point Likert rating scale $(\mathrm{SA}=5, \mathrm{~A}=4, \mathrm{UD}=3, \mathrm{DA}=2, \mathrm{SDA}=1)$. After the development of the final version of the research tool, it was personally administrated in the field. The response rate of the returning questionnaires was $100 \%$.

After data collection process, the collected data were organized, summarized and analyzed with the help of SPSS software (Version 20). The Mean and Standard Deviation were used as descriptive statistics to estimate the magnitude of sample statistics, while parametric test "one-way between groups ANOVA" was conducted as an inferential statistical technique for the data analysis; and to estimate the population parameters.

\begin{tabular}{llll}
\hline JISR-MSSE & Volume 1 & Number 15 & June 2017 \\
\hline
\end{tabular}




\section{RESULTS}

Table.2 Use of information and communication technology has a positive effect on teaching

\begin{tabular}{lcccccc}
\hline Respondents & $\boldsymbol{n}$ & $\boldsymbol{M}$ & $\boldsymbol{S D}$ & $\boldsymbol{F}$ & $\boldsymbol{p}$ & $\boldsymbol{\eta} \mathbf{2}$ \\
\hline Master Trainers & 37 & 3.57 & 1.042 & & & \\
Head Teachers & 84 & 3.23 & 1.155 & 8.959 & .000 & .06 \\
Secondary School Teachers & 175 & 3.91 & 1.308 & & & \\
Overall & 296 & 3.69 & 1.269 & & & \\
\hline
\end{tabular}

$* * * p<.001$

\section{Interpretation}

The value of overall mean perceptions $(\mathrm{M}=3.69, \mathrm{SD}=1.269)$ demonstrates that use of information and communication technology has a positive effect on teaching of secondary school teachers. The one-way ANOVA is used to compare significant mean differences between perceptions of the research participants of the three groups. The one-way ANOVA, F(2, 293) $=8.959, \mathrm{p}<.001, \eta 2=.06$ (medium effect size,), demonstrates statistically significant mean differences between perceptions of the three groups. Moreover, Tukey HSD test is conducted for Post Hoc comparisons between groups (Table 3).

Table.3 Tukey HSD Post Hoc Test of Multiple Comparisons

\begin{tabular}{|c|c|c|c|c|}
\hline \multirow{2}{*}{ Comparison } & \multirow{2}{*}{$M D$} & \multirow{2}{*}{$p$} & \multicolumn{2}{|c|}{$95 \% \mathrm{CI}$} \\
\hline & & & $L L$ & $U L$ \\
\hline Secondary School Teachers Vs Head Teachers & $.688 * * *$ & .000 & .30 & 1.07 \\
\hline
\end{tabular}

\section{Interpretation}

The above table shows significant mean difference MD $=.688,95 \%$ CI [.30, 1.07] between perceptions of secondary school teachers and head teachers at $\mathrm{p}<.001$ regarding "Use of ICT has a positive effect on teaching".

Table.4 Use of information and communication technology in Classroom Saves Lesson's Time

\begin{tabular}{lcccccc}
\hline Respondents & $\boldsymbol{n}$ & $\boldsymbol{M}$ & $\boldsymbol{S D}$ & $\boldsymbol{F}$ & $\boldsymbol{p}$ & $\boldsymbol{\eta}^{2}$ \\
\hline Master Trainers & 37 & 4.16 & 1.068 & & & \\
Head Teachers & 84 & 4.23 & 0.998 & 20.302 & .000 & .12 \\
Secondary School Teachers & 175 & 3.31 & 1.298 & & & \\
Overall & 296 & 3.68 & 1.269 & & & \\
\hline$* * * p<.001$ & & & & &
\end{tabular}




\section{Interpretation}

The magnitude of overall mean perceptions $(\mathrm{M}=3.68, \mathrm{SD}=1.269)$ of respondents of the study reflects that use of information and communication technology in classroom saves lesson's time. One-way ANOVA is used as inferential statistical test to compare significant mean differences between perceptions of the three groups. The one-way ANOVA, F $(2,293)=$ $20.302, \mathrm{p}<.001, \eta 2=.12$ (medium effect size), exhibit statistically significant mean differences between perceptions of the three groups. Furthermore, Tukey HSD procedure is run for Post Hoc comparisons (Table 5).

Table.5 Tukey HSD Post Hoc Test of Multiple Comparisons

\begin{tabular}{lcccc}
\hline \multicolumn{1}{c}{ Comparison } & \multirow{2}{*}{$\boldsymbol{M D}$} & $\boldsymbol{p}$ & \multicolumn{2}{c}{$\mathbf{9 5 \%} \mathbf{C I}$} \\
\cline { 4 - 5 } & & & $\boldsymbol{L L}$ & $\boldsymbol{U L}$ \\
\hline Secondary School Teachers Vs Head Teachers & $-.918 * * *$ & .000 & -1.29 & -.54 \\
\hline Secondary School Teachers Vs Master Trainers & $-.854 * * *$ & .000 & -1.36 & -.35 \\
\hline$* * * p<.001$ & & & &
\end{tabular}

\section{Interpretation}

Above table indicates significant mean difference MD $=-.918,95 \%$ CI $[-1.29,-.54]$ between perceptions of secondary school teachers and head teachers; and significant mean difference $\mathrm{MD}=-.854,95 \% \mathrm{CI}[-1.36,-.35]$ between perceptions of secondary school teachers and master trainers regarding "Use of information and communication technology in classroom saves lesson's time" at $\mathrm{p}<.001$.

Table.6 Teachers have proper skills to use information and communication technology

\begin{tabular}{lccccc}
\hline Respondents & $\mathrm{n}$ & $\mathrm{M}$ & $\mathrm{SD}$ & $\mathrm{F}$ & $\mathrm{p}$ \\
\hline Master Trainers & 37 & 2.41 & .644 & & \\
Head Teachers & 84 & 2.29 & .858 & 1.547 & .215 \\
Secondary School Teachers & 175 & 2.49 & .896 & & \\
Overall & 296 & 2.42 & .860 & & \\
\hline
\end{tabular}

$p>.05$ (ns)

\section{Interpretation}

The magnitude of the overall mean perceptions $(\mathrm{M}=2.42, \mathrm{SD}=.860)$ of the respondents of the study reflects that secondary school teachers do not have proper skills to use information and communication technology in instructional activities. The one-way ANOVA demonstrates a non-significant mean difference between perceptions of the three groups, $F(2,293)=$ $1.547, \mathrm{p}>.05$. 


\section{Interpretation}

The magnitude of the overall mean perceptions $(\mathrm{M}=2.42, \mathrm{SD}=.860)$ of the respondents of the study reflects that secondary school teachers do not have proper skills to use information and communication technology in instructional activities. The one-way ANOVA demonstrates a non-significant mean difference between perceptions of the three groups, $\mathrm{F}(2,293)=$ $1.547, \mathrm{p}>.05$.

Table.7 Information and communication technology provides easy access to a lot of information

\begin{tabular}{lcccccc}
\hline Respondents & $\boldsymbol{N}$ & $\boldsymbol{M}$ & $\boldsymbol{S D}$ & $\boldsymbol{F}$ & $\boldsymbol{p}$ & $\boldsymbol{\eta}^{\mathbf{2}}$ \\
\hline Master Trainers & 37 & 3.57 & 1.042 & & & \\
Head Teachers & 84 & 3.23 & 1.155 & 6.053 & .003 & .06 \\
Secondary School Teachers & 175 & 3.76 & 1.179 & & & \\
Overall & 296 & 3.58 & 1.176 & & & \\
\hline
\end{tabular}

$* * p<.01$

\section{Interpretation}

The magnitude of overall mean perceptions $(\mathrm{M}=3.58, \mathrm{SD}=1.176)$ of the research subjects demonstrates that information and communication technology provides easy access to a lot of information. The one-way ANOVA is used as an inferential statistical test to compare significant mean differences between perceptions of the three groups. The one-way ANOVA, F(2, $293)=6.053, p<.01, \eta 2=.06$ (medium effect size), indicates statistically significant mean differences between perceptions of the three groups. Also, Tukey HSD test is conducted for Post Hoc comparisons between groups (Table 8).

Table.8 Tukey HSD Post Hoc Test of Multiple Comparisons

\begin{tabular}{lccccc}
\hline \multicolumn{1}{c}{ Comparison } & MD & $\boldsymbol{p}$ & \multicolumn{2}{c}{$\mathbf{9 5 \%} \mathbf{C I}$} \\
\cline { 4 - 6 } & & & & $\boldsymbol{L}$ & $\boldsymbol{U} \boldsymbol{L}$ \\
\hline Secondary School Teachers Vs Head Teachers & $-.534 * *$ & .002 & -.90 & -.17 \\
\hline$* p<.01$ & & & &
\end{tabular}

\section{Interpretation}

Table 8 reflects a significant mean difference MD $=-.534,95 \%$ CI [-.90, -.17] between secondary school teachers and head teachers at $\mathrm{p}<.01$ about "information and communication technology provides easy access to a lot of information".

Table.9 Use of ICT requires more time and personal efforts

\begin{tabular}{lcccccc}
\hline Respondents & $\boldsymbol{N}$ & $\boldsymbol{M}$ & $\boldsymbol{S D}$ & $\boldsymbol{F}$ & $\boldsymbol{p}$ & $\boldsymbol{\eta}^{2}$ \\
\hline Master Trainers & 37 & 2.76 & 1.188 & & & \\
Head Teachers & 84 & 3.32 & 1.163 & 19.827 & .000 & .12 \\
Secondary School Teachers & 175 & 3.91 & 1.079 & & & \\
Overall & 296 & 3.60 & 1.186 & & & \\
\hline
\end{tabular}

$* * * p<.001$ 


\section{Interpretation}

The magnitude of overall mean perceptions $(M=3.60, \mathrm{SD}=1.186)$ of the research subjects demonstrates that use of information and communication technology requires more time and personal efforts of secondary school teachers. The one-way ANOVA is used as an inferential statistical test to compare significant mean differences between perceptions of the three groups. The one-way ANOVA, F(2, 293) = 19.827, $\mathrm{p}<.001, \eta 2=.12$ (medium effect size), indicates statistically significant mean differences between perceptions of the three groups. Furthermore, Tukey HSD procedure is conducted for Post Hoc comparisons between groups (Table 10).

Table.10 Tukey HSD Post Hoc Test of Multiple Comparisons

\begin{tabular}{|c|c|c|c|c|}
\hline \multirow{2}{*}{ Comparison } & \multirow{2}{*}{$M D$} & \multirow{2}{*}{$p$} & \multicolumn{2}{|c|}{$95 \% \mathrm{CI}$} \\
\hline & & & $L L$ & $\boldsymbol{U L}$ \\
\hline Secondary School Teachers Vs Head Teachers & $-.587 * * *$ & .000 & -.94 & -.24 \\
\hline Secondary School Teachers Vs Master Trainers & $.565 * * *$ & .000 & .05 & 1.08 \\
\hline Head Teachers Vs Master Trainers & $-1.152 *$ & .029 & -1.63 & -.68 \\
\hline
\end{tabular}

$* p<.05, * * * p<.001$

\section{Interpretation}

Table 10 reflects significant mean difference $\mathrm{MD}=-.587,95 \%$ CI $[-.94,-.24]$ between perceptions of secondary school teachers and head teachers at $\mathrm{p}<.001$; significant mean difference $\mathrm{MD}=.565,95 \% \mathrm{CI}[.05,1.08]$ between perceptions of secondary school teachers and master trainers at $\mathrm{p}<.001$; and significant mean difference $\mathrm{MD}=-1.152,95 \% \mathrm{CI}[-1.63$, -.68] between perceptions of head teachers and master trainers at $\mathrm{p}<.05$ regarding "Using information and communication technology requires more time and personal efforts".

Table.11 Information and communication technology Training is Useful for Teachers' Personal Development

\begin{tabular}{lcccccc}
\hline Respondents & $\boldsymbol{n}$ & $\boldsymbol{M}$ & $\boldsymbol{S D}$ & $\boldsymbol{F}$ & $\boldsymbol{p}$ & $\boldsymbol{\eta}^{\mathbf{2}}$ \\
\hline Master Trainers & 37 & 4.35 & .633 & & & \\
Head Teachers & 84 & 3.88 & .974 & 6.806 & .001 & .05 \\
Secondary School Teachers & 175 & 3.73 & .979 & & & \\
Overall & 296 & 3.85 & .961 & & & \\
$* p<.01$ & & & & &
\end{tabular}

\section{Interpretation}

The value of the overall mean perceptions $(M=3.85, \mathrm{SD}=.961)$ indicates that information and communication technology training is useful for teachers' personal development at the secondary level. The one-way ANOVA is used as an inferential statistical analysis to compare significant mean differences between perceptions of the three groups. The one-way ANOVA, $\mathrm{F}(2,293)=6.806, \mathrm{p}<.01, \eta 2=.05$ (small effect size), indicates statistically significant mean differences between perceptions of the three groups. Furthermore, Tukey HSD procedure is run for Post Hoc comparisons between groups (Table 12).

\begin{tabular}{llll}
\hline JISR-MSSE & Volume 1 & Number 15 & Jan-June 2017
\end{tabular}


Table.12 Tukey HSD Post Hoc Test of Multiple Comparisons

\begin{tabular}{|c|c|c|c|c|}
\hline \multirow{2}{*}{ Comparison } & \multirow{2}{*}{$M D$} & \multirow{2}{*}{$p$} & \multicolumn{2}{|c|}{$95 \% \mathrm{CI}$} \\
\hline & & & $L L$ & $\boldsymbol{U L}$ \\
\hline Secondary School Teachers Vs Head Teachers & $-.626 * *$ & .001 & -1.03 & -.22 \\
\hline Secondary School Teachers Vs Master Trainers & $-.470 *$ & .032 & -.91 & -.03 \\
\hline
\end{tabular}

\section{Interpretation}

The above table reflects significant mean difference $\mathrm{MD}=-.626,95 \% \mathrm{CI}[-1.03,-.22]$ between perceptions of secondary school teachers and master trainers at $\mathrm{p}<.01$; and significant mean difference MD $=-.470,95 \%$ CI [-.91, -.03] between perceptions of head teachers and master trainers at $\mathrm{p}<.05$ regarding "information and communication technology training is useful for teacher's personal development".

Table.13 ICT Helps Teachers' in Making Their Teaching More Effective

\begin{tabular}{lcccccc}
\hline Respondents & $\boldsymbol{n}$ & $\boldsymbol{M}$ & $\boldsymbol{S D}$ & $\boldsymbol{F}$ & $\boldsymbol{p}$ & $\boldsymbol{\eta}^{2}$ \\
\hline Master Trainers & 37 & 3.30 & 1.309 & & & \\
Head Teachers & 84 & 4.06 & 0.896 & 7.625 & .001 & .05 \\
Secondary School Teachers & 175 & 3.69 & 1.026 & & & \\
Overall & 296 & 3.75 & 1.054 & & & \\
\hline
\end{tabular}

$* * p<.01$

\section{Interpretation}

The magnitude of the overall mean perceptions $(\mathrm{M}=3.75, \mathrm{SD}=1.054)$ indicates that information and communication technology helps teachers' in making their teaching more effective at the secondary level. The one-way ANOVA is used as an inferential statistical test to compare significant mean differences between perceptions of the three groups. The one-way ANOVA, $\mathrm{F}(2,293)=7.625, \mathrm{p}<.01, \eta 2=.05$ (small effect size), indicates statistically significant mean differences between perceptions of the three groups. Furthermore, Tukey HSD procedure is run for Post Hoc comparisons between groups (Table 14).

Table.14 Tukey HSD Post Hoc Test of Multiple Comparisons

\begin{tabular}{llllll}
\hline \multicolumn{1}{c}{ Comparison } & MD & $\boldsymbol{p}$ & \multicolumn{2}{c}{$\mathbf{9 5 \%} \mathbf{C I}$} \\
\cline { 4 - 6 } Secondary School Teachers Vs Head Teachers & $-.368 *$ & .021 & -.69 & -.05 \\
\hline Secondary School Teachers Vs Master Trainers & $.762 * *$ & .001 & .28 & 1.24 \\
\hline$* p<.05, * * p<.01$ & & & &
\end{tabular}




\section{Interpretation}

Table 14 reflects statistically significant mean difference MD $=-.368,95 \%$ CI [-.69, -.05$]$ between perceptions of secondary school teachers and head teachers at $\mathrm{p}<.05$; and significant mean difference $\mathrm{MD}=.762,95 \%$ CI [.28, 1.24] between perceptions of head teachers and master trainers at $\mathrm{p}<.01$ regarding "information and communication technology helps teachers' in making their teaching more effective".

Table.15 ICT is a Valuable Tool for Teachers to Improve Classroom Activities

\begin{tabular}{lcccccc}
\hline Respondents & $\boldsymbol{n}$ & $\boldsymbol{M}$ & $\boldsymbol{S D}$ & $\boldsymbol{F}$ & $\boldsymbol{p}$ & $\boldsymbol{\eta}^{2}$ \\
\hline Master Trainers & 37 & 3.73 & 1.283 & & & \\
Head Teachers & 84 & 3.89 & 1.290 & 5.676 & .004 & .04 \\
Secondary School Teachers & 175 & 3.30 & 1.436 & & & \\
Overall & 296 & 3.52 & 1.400 & & & \\
\hline$* * p<.01$ & & & & &
\end{tabular}

\section{Interpretation}

The amount of the overall mean perceptions $(M=3.75, S D=1.054)$ reflects that information and communication technology is a valuable tool for teachers to improve classroom activities at the secondary level. The one-way ANOVA is used as an inferential statistical test to compare significant mean differences between perceptions of the three groups. The one-way ANOVA, $\mathrm{F}(2,293)=5.676, \mathrm{p}<.01, \eta 2=.04$ (small effect size), indicates statistically significant mean differences between perceptions of the three groups. Furthermore, Tukey HSD test is run for Post Hoc comparisons between groups (Table 16).

Table.16 Tukey HSD Post Hoc Test of Multiple Comparisons

$$
\begin{array}{llll}
\text { Comparison } & M D & p & \multicolumn{2}{c}{95 \% \mathrm{CI}} \\
& \mathrm{LL}
\end{array}
$$

\section{$95 \% \mathrm{CI}$}

\begin{tabular}{lllll}
\hline Secondary School Teachers Vs Head Teachers & $-.590 * *$ & .004 & -1.02 & -.16 \\
\hline
\end{tabular}

$* p<.05, * * p<.01$

\section{Interpretation}

Table 16 reflects statistically significant mean difference MD $=-.590,95 \%$ CI [-1.02, -.16] between perceptions of secondary school teachers and head teachers at $p<.011$ regarding "information and communication technology information and communication technology is a valuable tool for teachers to improve classroom activities".

Table.15 Table.17 Use of information and communication technology increases interaction between teacher and students

\begin{tabular}{lcccccc}
\hline Respondents & $\boldsymbol{n}$ & $\boldsymbol{M}$ & $\boldsymbol{S D}$ & $\boldsymbol{F}$ & $\boldsymbol{p}$ & $\boldsymbol{\eta}^{\mathbf{2}}$ \\
\hline Master Trainers & 37 & 3.92 & 1.038 & & & \\
Head Teachers & 84 & 3.61 & 1.098 & 7.668 & .001 & .05 \\
Secondary School Teachers & 175 & 3.20 & 1.208 & & & \\
Overall & 296 & 3.41 & 1.184 & & & \\
\hline$* * p<.01$ & & & & & \\
\hline JISR-MSSE & Volume 1 & & Number 15 & & Jan-June 2017 & $\mathbf{1 3 1}$
\end{tabular}




\section{Interpretation}

The level of overall mean perceptions $(M=3.75, \mathrm{SD}=1.054)$ demonstrates that use of information and communication technology increases interaction between teacher and students. The one-way ANOVA is applied as an inferential statistical test to compare significant mean differences between perceptions of the three groups. The one-way ANOVA, $\mathrm{F}(2,293)=7.668, \mathrm{p}<.01, \eta 2=.05$ (small effect size), represents statistically significant mean differences between perceptions of the three groups. Furthermore, Tukey HSD test is run for Post Hoc comparisons between groups (Table 18).

Table.18 Tukey HSD Post Hoc Test of Multiple Comparisons

\begin{tabular}{|c|c|c|c|c|c|c|}
\hline \multirow{2}{*}{\multicolumn{3}{|c|}{ Comparison }} & \multirow{2}{*}{$M D$} & \multirow{2}{*}{$p$} & \multicolumn{2}{|c|}{$95 \% \mathrm{CI}$} \\
\hline & & & & & $L L$ & $U \boldsymbol{L}$ \\
\hline \multicolumn{3}{|c|}{ Secondary School Teachers Vs Head Teachers } & $-.407 *$ & .023 & -.77 & -.05 \\
\hline \multicolumn{3}{|c|}{ Secondary School Teachers Vs Master Trainers } & $-.719 * *$ & .002 & -1.21 & -.23 \\
\hline \multicolumn{7}{|l|}{$* p<.05, * * p<.01$} \\
\hline \multicolumn{7}{|l|}{ Interpretation } \\
\hline \multicolumn{7}{|c|}{$\begin{array}{l}\text { Table } 18 \text { shows statistically significant mean difference MD }=-.407,95 \% \text { CI }[-.77,-.05] \\
\text { between perceptions of secondary school teachers and head teachers at } \mathrm{p}<.05 \text {; and significant } \\
\text { mean difference } \mathrm{MD}=-.719,95 \% \mathrm{CI}[-1.21,-.23] \text { between perceptions of secondary school } \\
\text { teachers and master trainers at } \mathrm{p}<.01 \text { regarding "Use of information and communication } \\
\text { technology increases interaction between teacher and students". }\end{array}$} \\
\hline \multicolumn{7}{|c|}{$\begin{array}{l}\text { Table.19 Table.19 Use of ICT helps teachers to understand difficult concepts in a more } \\
\text { effective way }\end{array}$} \\
\hline Respondents & $n$ & $M$ & $S D$ & $F$ & $p$ & $\eta^{2}$ \\
\hline Master Trainers & 37 & 3.81 & 1.151 & & & \\
\hline Head Teachers & 84 & 3.56 & 1.112 & 10.605 & .000 & .07 \\
\hline Secondary School Teachers & 175 & 3.02 & 1.201 & & & \\
\hline Overall & 296 & 3.27 & 1.208 & & & \\
\hline
\end{tabular}

$* * p<.001$

\section{Interpretation}

The level of the overall mean perceptions $(\mathrm{M}=3.75, \mathrm{SD}=1.208)$ reflects that use of information and communication technology helps teachers to understand difficult concepts in a more effective way at the secondary level. The one-way ANOVA is applied as an inferential statistical test to compare significant mean differences between perceptions of the three groups. The one-way ANOVA, F(2, 293) = 10.605, $\mathrm{p}<.001, \eta 2=.07$ (medium effect size), demonstrates significant mean differences between perceptions of the three groups. Furthermore, Tukey HSD procedure is run for Post Hoc comparisons (Table 20). 
Table.20 Tukey HSD Post Hoc Test of Multiple Comparisons

\begin{tabular}{lccccc}
\hline \multicolumn{1}{c}{ Comparison } & MD & $p$ & $L L$ & UL \\
\cline { 4 - 6 } & & & & \multicolumn{2}{c}{$\mathbf{9 5 \%}$ CI } \\
\hline Secondary School Teachers Vs Head Teachers & $-.542 * *$ & .002 & -.91 & -.18 \\
\hline Secondary School Teachers Vs Master Trainers & $-.794 * *$ & .001 & -1.29 & -.29 \\
\hline$* p<.01$ & & & &
\end{tabular}

\section{FINDINGS}

The key findings of this empirical research are described as:

1 It was found that use of information and communication technology has a positive effect on teaching of secondary school teachers. The one-way ANOVA demonstrated significant mean difference between perceptions of the three groups. But Tukey HSD test showed only significant mean difference between perceptions of secondary school teachers and head teachers regarding "Use of information and communication technology has a positive effect on teaching".

2 It was found that the magnitude of overall mean perceptions reflected that use of information and communication technology in classroom saves lesson's time. The one-way ANOVA exhibited statistically significant mean differences between perceptions of the three groups. Yet, there were only significant mean difference between perceptions of secondary school teachers and head teachers; and between perceptions of secondary school teachers and master trainers regarding "Use of information and communication technology in classroom saves lesson's time".

3 It was found that secondary school teachers do not have proper skills to use information and communication technology in their instructional activities. The one-way ANOVA demonstrated a non-significant mean difference between perceptions of the three groups.

4 It was found that information and communication technology provides easy access to a lot of information. The one-way ANOVA demonstrated statistically significant difference between perceptions of the three groups. Only significant mean difference was found between perceptions of secondary school teachers and head teachers about "information and communication technology provides easy access to a lot of information".

5 It was found that use of ICT requires more time and personal efforts of secondary school teachers. The one-way ANOVA indicated statistically significant mean difference between groups. Post Hoc comparison reflected significant mean difference between perceptions of all groups regarding use of information and communication technology requires more time and personal efforts.

6 It was found that information and communication technology training is useful for teachers' personal development at the secondary level. The one-way ANOVA indicated statistically significant mean differences between perceptions of the three groups. Furthermore, Tukey HSD Post Hoc comparison reflected significant mean differences

\begin{tabular}{llll}
\hline JISR-MSSE & Volume 1 & Jumber 15 & Jane 2017 \\
\hline
\end{tabular}


between perceptions of secondary school teachers and master trainers; and between perceptions of head teachers and master trainers regarding ICT training is useful for teacher's personal development.

7 It was found that information and communication technology helps teachers' in making their teaching more effective at the secondary level. The one-way ANOVA indicated statistically significant differences between perceptions of the three groups. Tukey HSD Post Hoc comparison reflected significant mean difference between perceptions of secondary school teachers and head teachers; and between head teachers and master trainers regarding information and communication technology helps teachers' in making their teaching more effective.

8 It was found that information and communication technology is a valuable tool for teachers to improve classroom activities at the secondary level. The one-way ANOVA indicated statistically significant mean differences between perceptions of the three groups. Tukey HSD Post Hoc comparison reflected only significant mean difference between perceptions of secondary school teachers and head teachers regarding ICT is a valuable tool for teachers to improve classroom activities.

9 It was found that use of information and communication technology increases interaction between a teacher and students. The one-way ANOVA represented statistically significant mean difference between perceptions of the three groups. Tukey HSD Post Hoc comparison showed significant mean difference between perceptions of secondary school teachers and head teachers; and between secondary school teachers and master trainers regarding use of ICT increases interaction between a teacher and students.

10 It was found that use of information and communication technology helps teachers to understand difficult concepts in a more effective way at the secondary level. The one-way between groups ANOVA demonstrated significant mean differences between perceptions of the three groups. Furthermore, Tukey HSD Post Hoc comparison revealed significant mean difference between perceptions of secondary school teachers and head teachers; and significant mean difference between secondary school teachers and master trainers regarding use of ICT helps teachers to understand difficult concepts in a more effective way at the secondary level.

\section{DISCUSSION}

This section compares the findings of this study to the findings of the prior researches in this area. Traditional teaching methodologies, techniques, and strategies are not fulfilling the needs and aspirations of students, stakeholders, and the entire education system; and are obstacles in the way forward. To go ahead from these hindrances, it is essential to update teachers existing knowledge and skills. But it is only possible when teachers have personal commitment, motivation, and dedication to learn new knowledge and skills about modern technologies such as information and communication technology, which is being used for last few decades in the education system for the improvement of teachers' knowledge and skills.

According to Russell (1999), information and communication technology for teachers' professional development is seen as a potential vehicle that brings transformation and

134 Jan-June 2017 Volume $1 \quad$ Number $15 \quad$ JISR-MSSE


innovations in teacher education. Professional development can change the way of teaching and learning if information and communication technology is used appropriately and effectively in teacher education. Information and communication technology enables to teachers, to apply an interactive approach for teaching students in classroom. These findings are also consistent with the finding of present study that use of information and communication technology increases interaction between teacher and students.

It was found that information and communication technology provides easy access to a lot of information. Similar were the finding of Barron (1998) and Hew and Brush (2007) that information and communication technology allow teachers to explore and discover new bodies of knowledge and skills for updating their existing knowledge and skills.

Information and communication technology helps teachers in making their teaching more effective; and is considered as a valuable tool for teachers to improve classroom activities at the secondary level. This finding is also in line with findings of Alben (2006), Lebow (1993), and Reeves and Jonassen (1996) that information and communication technology has enormous potential for improving quality of teacher education. Teachers who use information and communication technology tools for learning purposes, can enhance their mental capabilities, and improve their attitudes and perceptions towards classroom activities such as instruction, knowledge of educational psychology, classroom management, students' discipline, and students' assessment, and evaluation.

ICT also saves time and helps teachers to improve their quality of work. ICT has made it simple for teachers to update and upgrade teaching and learning material on internet (Ali, Haolader, \& Muhammad, 2013). These findings also support the present study' finding that ICT helps secondary school teachers to save time during instruction and improve the quality of work.

Majoka, Fazal, and Khan (2013) and Ndibalema (2014) found that teachers have insufficient knowledge and skills toward ICT use in their pedagogical activities. The present study also supports to their finding that secondary school teachers are not fully skilled towards the use of ICT in their pedagogical activities for the improvement of current practices.

Now, developed countries' teachers are using information and communication technology to make their instructional work effective, because the use of ICT facilitates teachers to save time in the preparation of lectures and during instructional activities in the classroom (Baek, Jong, $\& \mathrm{Kim}, 2008)$. The researcher also explored through the perceptions of the respondents of the study that use of information and communication technology during instructional activities saves time and teachers delivers their lecture in a short time that traditional methods of pedagogy.

It was also explored that use of information and communication technology during instruction increases interaction between a teacher and students. This finding is also corroborated that findings of the Giordano (2007) and Hammond (1998) that information and communication technology can elevate communication and interaction between a teacher and students.

Similarly, it was also found through this study that use of information and communication technology helps teachers to understand difficult concepts in a more effective way at the

\begin{tabular}{lllll}
\hline JISR-MSSE & Volume 1 & Number 15 & Jan-June 2017
\end{tabular}


secondary level. This finding is also in line with the finding of Mwalongo (2011), who delved that with the help of ICT, teachers can understand difficult themes, ideas, and concepts in an effective way through internet to improve their information about a particular topic or area, and consequently improve their classroom practices.

\section{SUMMARY}

The aim of the present empirical study is to explore the perceptions of research subjects regarding the usability of ICT as a tool for professional development of public sector secondary school teachers of the province Punjab, Pakistan. A number of studied have been already conducted in different contexts to investigate the usability of ICT as a tool for professional development of teachers. These studies explored different factors which motivate and encourage teachers in use ICT for the improvement of their pedagogical activities (e.g., Alben, 2006; Ali, Haolader, \& Muhammad, 2013; Baek, Jong, \& Kim, 2008; Barron, 1998; Giordano, 2007; Hammond , 1998; Hew \& Brush, 2007;Lebow, 1993; Mwalongo, 2011; Reeves \& Jonassen, 1996; Russell, 1999).

The major objective of the study is to explore the secondary school teachers' attitudes towards the use of ICT for their professional development. Therefore, after extensive study of the pertinent literature, the following items were taken in the research instruments to estimate the perceptions of research subjects regarding the use of ICT for professional development of secondary school teachers, viz: use of ICT has a positive effect on teaching, use of ICT in classroom saves lesson time, teachers have proper skills to use ICT, ICT provides easy access to a lot of information, using ICT requires more time and personal efforts, ICT training is useful for teachers' personal development, ICT helps teachers in making their teaching more effective, ICT is a valuable tool for teachers to improve classroom activities, use of ICT increases the interaction between teacher and students, and use of ICT helps teachers to understand difficult concepts in a more effective way. A survey study was also conducted in Punjab by Majoka, Fazal, and Khan (2013) and found that teachers have insufficient knowledge and skills toward ICT use in their pedagogical activities.

This study is descriptive survey type in nature. The quantitative approach was used to conduct this study. The target population or universe of this study was consisted of all Punjab public secondary schools' teachers and head teachers, and master trainers of Directorate of Staff Development in province Punjab. The sampling population is comprised of 1,746 secondary school teachers, 838 head teachers of public secondary school in Faisalabad division, and 122 master trainers of the Directorate of Staff Development who are engage in secondary school teachers' professional development in four districts (e.g., Chiniot, Jhang, Faisalabad, Toba Tek Singh) of the Faisalabad division. Through proportionate stratified random sampling technique, a sample of 175 secondary school teachers, 84 head teachers, and 37 master trainers is drawn.

A self-developed and structured questionnaire was used as a research instrument. The perceptions of the respondents were measured on a five point Likert rating scale ( $\mathrm{SA}=5, \mathrm{~A}=$ $4, \mathrm{UD}=3, \mathrm{DA}=2, \mathrm{SDA}=1$ ). After the development of the final version of the research tool, it was personally administrated in the field. The Mean and Standard Deviation are used as descriptive statistics to estimate the magnitude of sample statistics, while parametric test "one-way between groups ANOVA" is conducted as inferential statistical technique.

136 Jan-June 2017 Volume $1 \quad$ Number $15 \quad$ JISR-MSSE


The findings of this study proved that that use of information and communication technology has a positive effect on teaching, ICT saves lesson's time during instruction in class room, ICT provide easy access to a lot of information through Internet and online teaching, use of information and communication technology requires more time and personal efforts of teachers, ICT based training is useful for teachers' personal development, it helps teachers' in making their teaching more effective, ICT is a valuable tool for teachers to improve classroom activities, it increases interaction between a teacher and students, and it can help teachers to understand difficult concepts in a more effective way at the secondary level. On the basis of the results of present study, it was proved that ICT is a very significant and effective tool to improve the professional development of secondary school teachers.

\section{CONCLUSIONS AND RECOMMENDATIONS}

On the basis of the results of the present empirical study, it is investigated that use of information and communication technology is a powerful tool for the improvement of teachers' professional development. Therefore, the major conclusions of this study are described as: ICT has a positive effect on teaching, ICT saves lesson's time during instruction, ICT provide easy access to a lot of information through Internet and online teaching, the use of information and communication technology requires more time and personal efforts of teachers, ICT based training is useful for teachers' personal development, it helps teachers' in making their teaching more effective, ICT is a valuable tool for teachers to improve classroom activities, it also increases interaction between teacher and students, and it can also help teachers to understand difficult concepts in a more effective way at the secondary level. But it is also found that a number of public secondary school teachers are not competent towards the proper usability of ICT due to having their poor ICT based knowledge and skills.

The major cause of the improper usability of ICT in classroom and lack of poor ICT based knowledge and skills of secondary school teachers is that in-service teachers are only sent for professional development in short duration training programs and refresher courses. These formal activities do not fully train and encourage to public school teachers as how to integrate and use ICT in classroom teaching; and thus these are not proving so effective. In these trainings and refresher courses focus is only on Windows, word processors, MS Word, MS Power Point, and MS Excel in particular but teachers do no train as how to integrate and use ICT in their pedagogical activities. Furthermore, teachers are particularly trained in using computer and Internet but do not train them as how to use ICT in classroom activities. Also, all public secondary school teachers do not make use of Internet for online learning in classroom. Moreover, these trainings and refresher courses for teachers in ICT must be run in an effective and progressive mode, and the focus of the secondary school teachers' ICT based training should be on the use of ICT in pedagogical activities and integration of ICT in the delivery of content matter.

Therefore, it is recommended that Punjab Education Department should conduct long term information and communication technology based trainings, refresher courses, and workshops for teachers regarding the proper usability of information and communication technology in secondary level public schools; and for the improvement of information and communication technology based knowledge and skills of secondary school teachers of public sector schools. Moreover, these training programs and refresher courses in ICT must be run in an effective and progressive way. It is also recommended that similar studies should also be done to compare the usability of ICT for professional development of secondary school teachers of both public and private sector schools.

\begin{tabular}{llll}
\hline JISR-MSSE & Volume 1 & Number 15 & Jan-June 2017 \\
\hline
\end{tabular}




\section{REFERENCES}

Abuhmaid, A. (2011). ICT training courses for teacher professional development in Jordan. Turkish Online Journal of Educational Technology, 10 (4), 195-210.

Alben, R. (2006). Modern technology as a denaturalizing force. Policies \& Praxis, 4 (4), 289-302.

Ali, G., Haolader, F. A., \& Muhammad, K. (2013). The Role of ICT to Make TeachingLearning Effective in Higher Institutions of Learning in Uganda. International Journal of Innovative Research in Science, Engineering and Technology, 2 (8), 4041-4073.

Al-Madani, F. M., \& Allaafiajiy, I. A. (2014). Teachers' professional development on ICT use: a Saudi sustainable development model. Proceeding of the Global Summit on Education GSE 2014 (E- ISBN 978-967-11768-5-6) 4-5 March 2014, Kuala Lumpur, MALAYSIA. Organized by WorldConferences.net

Andoh, C. B. (2013). Factors influencing teachers' adoption and integration of information and communication technology into teaching. International Journal of Education and Development using Information and Communication Technology, 8 (1), 136-155.

Armstrong, A. (1999). Where is the teacher in the technology? Boston: Allyn and Bacon.

Ajzen, I. (1998). Attitudes, personality, and behaviour. Chicago: Dorsey Press.

Baek, Y. G., Jong, J., \& Kim, B. (2008). What makes teachers use of technology in the classroom? Exploring the factors affecting facilitation of technology with a Korean sample. Computers and Education, 50 (8), 224-234.

Barron, A. (1998). Designing Web-based training. British Journal of Educational Technology, 29 (04), 355-371.

Brinkerhoff, J. (2006). Effect of long-duration Professional development academy on technology skills, computer self-efficacy and technology integration beliefs and practices. Journal of Research on Technology in Education, 39 (1), 22-43.

Bonifacio, A. L. (2014). Developing Information Communication Technology (ICT) Curriculum Standards for K-12 Schools in the Philippines. Educational Technology \& Society, 9(2), 1-12.

Campbell, N. (2001). Information and communication technology: The teacher does not know everything! Inc.

Carlson, S., \& Gadio, C. T. (2002). Teacher professional development in the use of technology. In W. D.

Haddad, \& A. Draxler (Eds.), Technologies for education: Potentials, parameters and prospects (pp. 118-132).

138 Jan-June 2017 Volume $1 \quad$ Number $15 \quad$ JISR-MSSE 
Paris/Washington, D. C., UNESCO/Academy for Educational Development.

ChanLin, L., Hong, J., Horng, J., Chang, S., \& Chu, H. (2006). Factors influencing Technology Integration in teaching: a Taiwanese perspective. Innovations in Education and Teaching International, Pro Quest Education Journals, 43 (1), 57-68.

Clausen, J. M. (2007). Beginning teachers' technology use: First-year teacher development and the institutional context's affect on new teachers' instructional technology use with students. Journal of Research on Technology in Education, 39 (3) 245-261.

Condie, R., \& Livingston, K. (2007). Blending online learning with traditional approaches: changing practices. British Journal of Educational Technology, 38 (2), 337-348.

Cope, C., \& Ward, P. (2002). Integrating learning technology into classrooms: The importance of teacher perceptions. Educational Technology \& Society, 05 (1), 67-74.

Cubukcuoglu, B.(2013). Factors enabling the use of technology in subject teaching. International Journal of Education and Development using Information and Communication Technology (IJEDICT), 09 (03), 50-60.

Davis, N. (2000). International Contrast of Information Technology in Teacher Education: Multiple perspectives of change. Journal of Technology for Teacher Education, 9 (2), 139-147.

Giordano, V. (2007). A Professional Development Model to promote internet integration into P-12 teachers' practice: A mixed method study. Computers in the schools, 24 (34), 111-123.

Government of Pakistan (1947). Proceedings of the Educational Conference, Ministry of the Interior, Education Division, Karachi, pp. 421-22.

Government of Pakistan (1959). The Report of Commission on National Education, Ministry of Education, Islamabad, pp. 259,284.

Government of Pakistan (1965). Third Five-year plan, 1965-1970. Planning Commission, Islamabad, mp. 185.

Government of Pakistan (1969). The new education policy 1969-70. Islamabad: Ministry of Education. Government of Pakistan.

Government of Pakistan (1972). The National Education Policy 1972-80. Ministry of Education, Islamabad. p.34.

Government of Pakistan (1979). The National Education Policy and Implementation Program. Ministry of Education, Islamabad. pp. 23-24. 
Government of Pakistan (1998). The National Education Policy 198-2010, Ministry of Education, Islamabad, pp.72,74.

Government of Pakistan (2000). The IT Policy and Action Plan, Ministry of Science and Technology, Islamabad, pp. 29-38.

Government of Pakistan (2009). The National Education Policy 2009, Ministry of Education, Islamabad, pp. 42-44.

Grabe, M., \& Grabe, C. (2001). Integrating Technology for Meaningful Learning (2nd ed.). Houghton; USA: Muffin Company.

Grace, D. (1999). Paradigm lost and regained. Independent School, 59 (1), 54-57.

Haddad, W., \& Jurich, D. (2002). Technology and Teacher Education: Making the Connection. Editorial Technologia. Oakton: Academy for Educational Development.

Hammond, M. (1998). Learning through on-line discussion: What are opportunities for professional development and what are the characteristics of on-line writing? Journal of Information technology for Teacher Education, 7 (3), 331-346.

Hasibuan, S. (2013). A model of continuing professional competency development by using ICT (study at senior high school teachers Padangsidimpuan, North Sumatera). International Journal of Educational Administration and Policy Studies, 5 (6), 91-101.

Hew, K. F., \& Brush, T. (2007). Integrating technology into K-12 teaching and learning current knowledge gaps and recommendations for future research. Educational Technology Research and Development, 55 (3), 223-253. doi: 10.1007/s11423-006-9022-5

Kisirkoi, F. K. (2015). Integration of ICT in Education in a Secondary School in Kenya: A Case Study. Literacy Information and Computer Education Journal (LICEJ), 6 (2), 1904-1909.

Lebow, D. (1993). Constructivist values for instructional systems design: Five principles towards a new mindset. Educational Technology, Research and Development, 41 (3), 04-16.

Majoka, M. I., Fazal, S., \& Khan, M. S. (2013). Implementation of Information and Communication Technologies (ICTs) in Education Course: A Case from Teacher Education Institutions in Pakistan. Bulletin of Education and Research, 35 (2), 37-53

Mwalongo, A. (2011). Teachers' perceptions about ICT for teaching, professional development, administration and personal use. International Journal of Education and Development using Information and Communication Technology (IJEDICT), 7 (3), 36-49.

Ndibalema, P. (2014). Teachers' Attitudes towards the Use of Information Communication Technology (ICT) as a Pedagogical Tool in Secondary Schools in Tanzania: The Case of Kondoa District. International Journal of Education and Research, 2 (2), 1-16. 
Neyland, E. (2011). Integrating online learning in NSW secondary schools: Three schools perspectives on ICT adoption. Australia Journal of Educational Technology, 27 (1), 152-173.

Norris, C. T., Sullivan, J., Poirot. M., \& Soloway, E. (2003). No access, no use, no impact: Snapshot surveys of educational technology in K-12. Journal of Research on Technology in Education, 36 (1), 15-27.

Passey, D., \& Samways, B. (1997). Information Technology: supporting change through teacher education. London: Chapman \& Hall.

Razzak, N. A. (2015). Challenges facing school leadership in promoting ICT integration in instruction in the public schools of Bahrain. Educ Inf Technol, 20 (2), 303-318. doi:10.1007/s10639-013-9283-7

Reeves, T., \& Jonassen, D. (1996). Learning with technology: Using computers as cognitive tools. In D. Jonassen (Ed.), Handbook of Research Educational on Educational Communications and Technology (pp. 693-719). New York: Macmillan.

Russell, G. (1999). Implications of the 1999 DEST report for Professional Development in Learning Technology. Paper presented at the ACEC2000, the Australasian Computers in Education Conference," Learning Technologies, Teaching and the Future of Schools", Melbourne, Australia.

Semenov, A. (2005). Information and Communication Technologies in schools: A handbook for teachers, or how ICT can create new, open learning environments. Paris, France: United Nations Educational, Scientific and Cultural Organization.

Twining, P., \& Henry, F. (2014). Enhancing 'ICT Teaching' in English Schools: Vital Lessons. World Journal of Education, 4 (2), 45-58.

Twining, P., Davis, N., Charania, A., Chowfin, A., Henry, F., Nordin, H., \& Woodward, C. (2015). Developing new indicators to describe digital technology infrastructure in primary and secondary education. Montreal: UNESCO Institute for Statistics UNESCO (2010). ICT competency standards for teachers: implementation guidelines, version 1, from http://cst.unesco-ci.org/sites/projects/cst/default.aspx. Retrieved on May 01, 2015.

Wee, M. C., \& Bakar, Z. A. (2006). Obstacles towards the use of ICT tools in teaching and Learning of information system in Malaysia universities. The International Arab Journal of Information Technology, 3 (3), 203-209.

Yukselturk, E., \& Bulut, S. (2009).Gender differences in self-regulated online learning environment. Journal of Educational Technology \& Society, 2 (3), 12-22. 


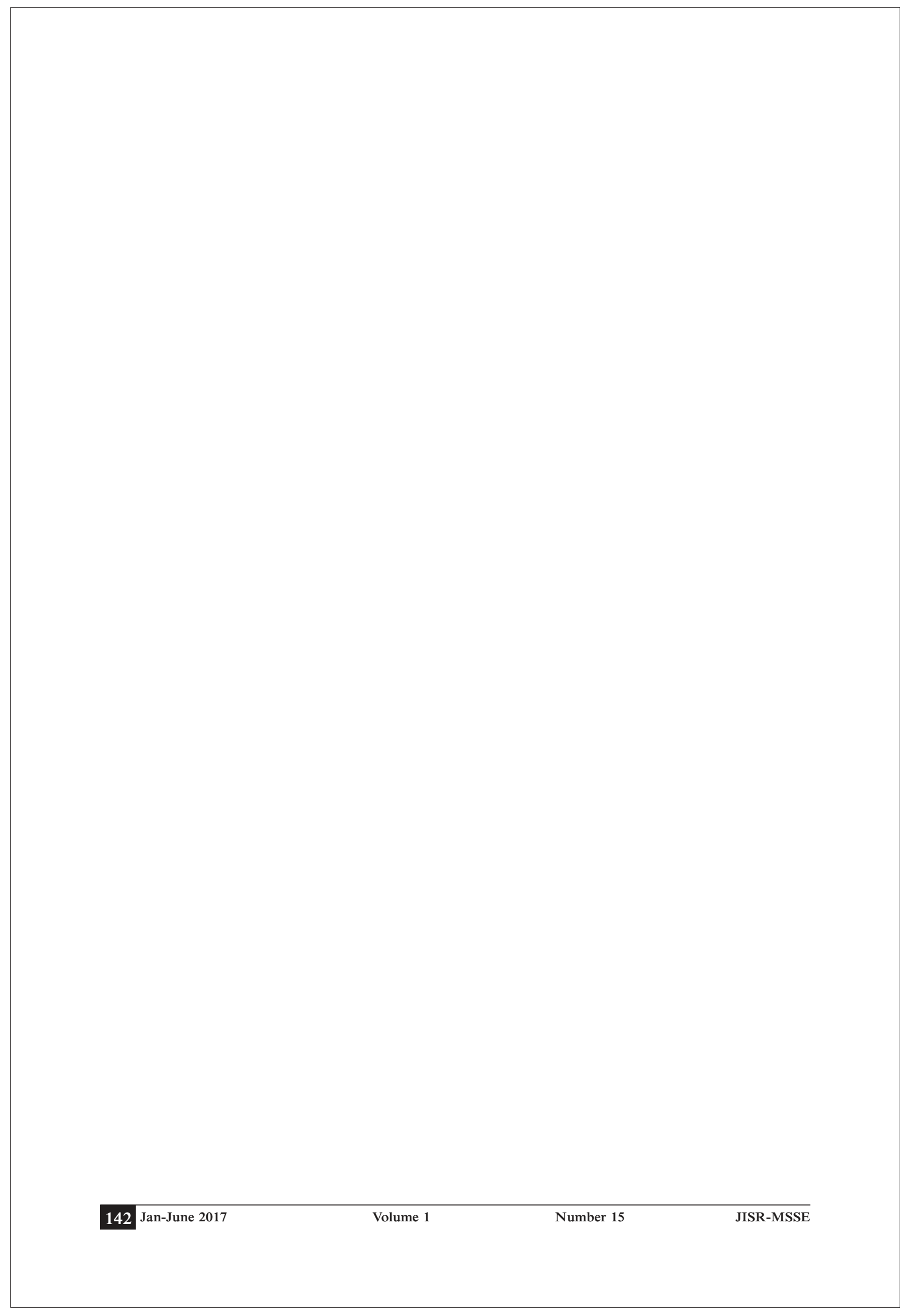

